\title{
Zastosowanie modulatorów receptorów sfingozyno-1-fosforanu w leczeniu nieswoistych chorób zapalnych jelit
}

\section{lek. Kamil Szymaszkiewicz ${ }^{1}$,}

lek. Agata Szymaszkiewicz²,

\author{
prof. dr hab. n. med. Jakub \\ Fichna $^{2 \square}$
}

${ }^{1}$ Zakład Farmakologii i Toksykologii, Międzywydziałowa Katedra Farmakologii Ogólnej i Klinicznej, Uniwersytet Medyczny w Łodzi ${ }^{2}$ Zakład Biochemii, Katedra Chemii i Biochemii Medycznej, Uniwersytet Medyczny w Łodzi

https://doi.org/10.18388/pb.2020_310

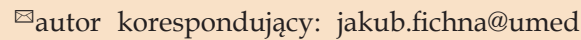
lodz.pl

Słowa kluczowe: nieswoiste choroby zapalne jelit, choroba Leśniowskiego-Crohna, wrzodziejące zapalenie jelita grubego, sfingozyny, fingolimod

Lista skrótów: ChLC - choroba Leśniowskiego-Crohna, DSS - siarczan dekstranu sodu (ang. dextran sulfate sodium), NChZJ - nieswoiste choroby zapalne jelit, WZJG - wrzodziejące zapalenie jelita grubego, S1P - sfingozyno-1-fosforan, S1PR - receptor dla sfingozyno-1-fosforanu, SPL - liaza sfingozyno-1-fosforanu, SphK1/SphK2 - kinaza sfingozyny typu $1 /$ typu 2, STAT3 - czynnik transkrypcyjny STAT3 (ang. signal transducer and activator of transcription 3), TNBS - kwas 2,4,6-trinitrobenzenosulfonowy

\section{STRESZCZENIE}

fingozyno-1-fosforan (S1P) jest przedstawicielem sfingolipidów o wysokiej aktywno$\checkmark$ ści biologicznej. Ze względu na swój wpływ na migrację komórek odpornościowych uznawany jest za istotny element w patogenezie wielu chorób, takich jak: toczeń układowy, stwardnienie rozsiane czy nieswoiste choroby zapalne jelit (NChZJ). Nieswoiste choroby zapalne jelit to grupa przewlekłych i postępujących schorzeń układu pokarmowego, które przebiegają z okresami zaostrzeń i remisji. Do najczęstszych zalicza się: chorobę Leśniowskiego-Crohna (ChLC) oraz wrzodziejące zapalenie jelita grubego (WZJG). Obecnie w leczeniu NChZJ stosuje się związki o działaniu przeciwzapalnym i immunomodulującym, których zadaniem jest zlagodzenie objawów oraz wprowadzenie pacjenta w stan remisji. W ramach tego artykułu omówiona zostanie rola S1P, receptora dla S1P oraz enzymów biorących udział w jego metabolizmie w warunkach fizjologicznych oraz w przebiegu NChZJ. Ponadto, podsumowane zostaną wyniki badań przedklinicznych i klinicznych nad skutecznością modulatorów receptora dla S1P w przebiegu NChZJ.

\section{WSTĘP}

Sfingolipidy stanowią grupę związków lipidowych, które występują we wszystkich komórkach eukariotycznych i wielu komórkach prokariotycznych. Stanowią one ważny składnik błon komórkowych, warunkujący prawidłowy kształt komórki. Ponadto, oprócz funkcji budulcowej sfingolipidy pełnią także rolę cząsteczek sygnałowych. Szkielet sfingolipidów stanowi sfingozyna, zbudowana z 18-węglowego łańcucha, zawierającego jedno podwójne wiązanie (C4-C5), dwie grupy hydroksylowe (C1, C3) oraz grupę aminową (C2). Sfingozyna powstaje $\mathrm{w}$ wyniku reakcji katalizowanej przez ceramidazę z cząsteczki ceramidu (będącego składnikiem wyjściowym do syntezy sfingolipidów). Nieaktywna biologicznie sfingozyna ulega przekształceniu w sfingozyno-1-fosforan (S1P, ang. sphingosine-1-phosphate) w wyniku działania kinaz sfingozyny: kinaza typu 1 (SphK1) i typu 2 (SphK2) (Ryc. 1) [1]. Kinazy te różnią się ze względu na swoją lokalizację i znaczenie biologiczne: kinaza typu 1 jest obecna w cytozolu komórki (głównie płytek krwi), dzięki temu płytki krwi stanowią najważniejsze źródło krążącego w krwioobiegu S1P, podczas gdy SphK2 występuje w jądrze komórkowym i siateczce śródplazmatycznej i warunkuje stężenie wewnątrzkomórkowego S1P. Produkowany przez płytki krwi S1P powstaje w wyniku fosforylacji sfingozyny, której źródłem są endogenne sfingolipidy lub sfingozyna pochodząca z osocza [2]. W metabolizmie S1P, przeciwwagę dla kinaz stanowią fosfatazy (fosfatazy specyficzne dla S1P typu 1 oraz typu 2) oraz liazy (SPL), które warunkują rozpad S1P.

Warto zauważyć, że drugim, obok płytek krwi, ważnym źródłem krążącego we krwi S1P są erytrocyty. Ze względu na to, że w erytrocytach nie stwierdza się ekspresji SPL, a aktywność SphK jest niska, stanowią one bezpieczny magazyn dla S1P i uczestniczą w regulacji jego poziomu we krwi [3].

Działanie biologiczne S1P jest możliwe dzięki interakcjom z receptorami dla S1P (S1PR). Ze względu na swoją różnorodną lokalizację, izoformy tego receptora (wyróżnia się 5 izoform S1PR: S1PR1 - S1PR5) pełnią różne funkcje, m.in. wspierają integralność bariery nabłonkowej (S1PR1 - S1PR3), regulują napięcie naczyń krwionośnych (S1PR2, S1PR3) czy kontrolują migrację limfocytów (S1PR1, S1PR5) (Tab. 1) [4]. Receptory typu pierwszego, S1PR1, wykazują wysoką ekspresję na powierzchni limfocytów i biorą udział w ich dojrzewaniu (w szczególności w procesie uwalniania ich z narządów limfatycznych).

Stężenie S1P jest wysokie we krwi i limfie, a niskie w tkankach i płynie śródmiąższowym. Ten swoisty gradient stężeń S1P między krwią/limfą a węzłami chłonnymi pełni kluczową rolę $\mathrm{w}$ procesie cyrkulacji limfocytów między krwioobiegiem a miejscem ich wytwarzania/dojrzewania [5]. Oprócz swojego 


\section{ceramid}

syntaza ceramidu $\uparrow$ ceramidaza

sfingozyna

\author{
fosfataza S1P $\uparrow$ SphK \\ sfingozyno-1-fosforan \\ $S P L$
}

\section{heksadekanol + fosfatydyloetanoloamina}

Rycina 1. Schemat przedstawiający metabolizm sfingolipidów. S1P - sfingozyno-1-fosforan, SphK - kinaza sfingozyny, SPL - liaza sfingozyno-1-fosforanu.

działania na populację komórek układu odpornościowego, S1P uczestniczy także w aktywacji molekuł uczestniczących w regulacji stanu zapalnego, proliferacji komórek oraz ich śmierci: NF-kB (ang. nuclear factor kappa B) oraz STAT3 (ang. signal transducer and activator of transcription 3) [6,7]. Z tego względu wskazuje się na istotną rolę S1P w rozwoju chorób autoimmunologicznych, takich jak toczeń rumieniowaty układowy, łuszczyca, cukrzyca typu 1 czy nieswoiste choroby zapalne jelit (NChZJ) (Ryc. 2).

Nieswoiste choroby zapalne jelit stanowią grupę przewlekłych, nawracających i postępujących schorzeń układu pokarmowego, które związane są z uszkodzeniem błony śluzowej i obecnością stanu zapalnego. Do najczęstszych zalicza się chorobę Leśniowskiego-Crohna (ChLC) oraz wrzodziejące zapalenie jelita grubego (WZJG). Dotychczas nie opracowano metody pozwalającej na wyleczenie NChZJ lub skutecznego sposobu profilaktyki rozwoju tych chorób. Obecnie w leczeniu stosuje się związki o działaniu przeciwzapalnym, których zadaniem jest złagodzenie objawów oraz poprawa jakości życia przez wprowadzenie pacjenta $\mathrm{w}$ stan remisji. Niestety nie ma specyficznych terapeutyków, które zatrzymałyby rozwój tej choroby, umożliwiły utrzy-

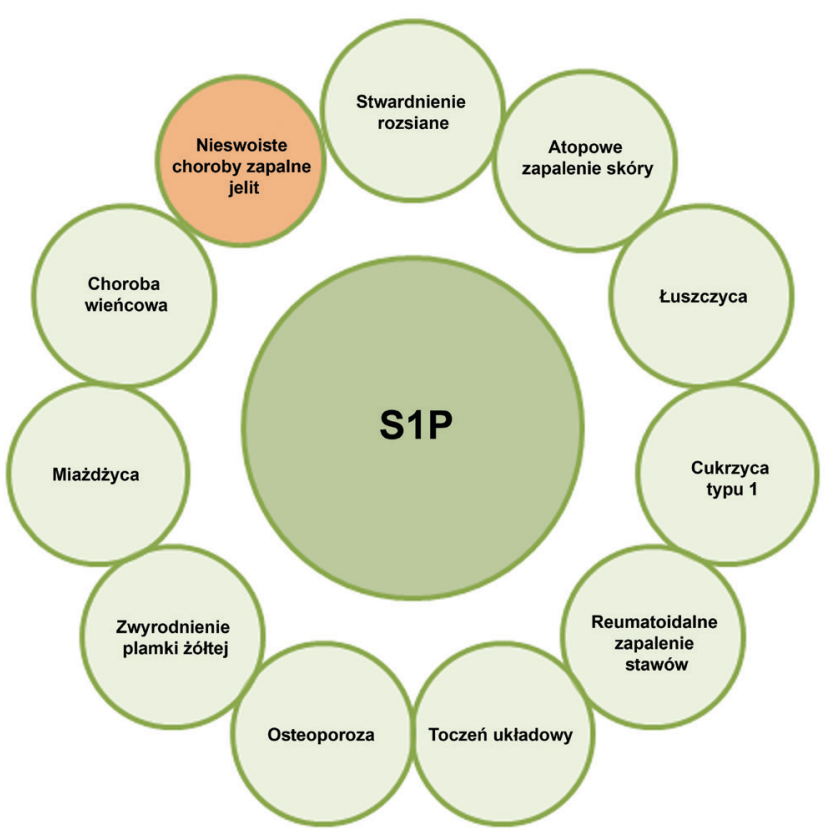

Rycina 2. Rola sfingozyno-1-fosforanu (S1P) w patogenezie chorób.

manie długotrwałej remisji i których działanie pozbawione byłoby efektów ubocznych. Z tego względu niezbędne jest opracowanie nowych metod leczenia NChZJ. W ostatnich latach modulatory receptora dla sfingozyno-1-fosforanu okazały się obiecującą strategią w leczeniu NChZJ.

W ramach tego artykułu przeglądowego omówiona zostanie rola S1P oraz enzymów uczestniczących w jego metabolizmie w patogenezie oraz leczeniu NChZJ.

\section{ROLA S1P W PRZEBIEGU NChZJ}

W warunkach homeostazy organizmu, stężenie S1P w jelitach jest bardzo niskie. Jest to związane $\mathrm{z}$ niską ekspresją kinaz S1P oraz wysoką aktywnością SPL w enterocytach

Tabela 1. Lokalizacja i rola receptorów dla sfingozyno-1-fosforanu (S1PR).

\begin{tabular}{|c|c|c|}
\hline Typ receptora & Lokalizacja & Rola \\
\hline S1PR1 & $\begin{array}{l}\text { Limfocyty } \\
\text { Komórki śródbłonka } \\
\text { Kardiomiocyty } \\
\text { Komórki mięśni gładkich } \\
\text { Komórki układu nerwowego } \\
\text { Oligodendrocyty }\end{array}$ & $\begin{array}{l}\text { Uwalnianie limfocytów z narządów limfatycznych } \\
\text { Zahamowanie działania komórek Treg } \\
\text { Rozwój embrionalny układu krążenia } \\
\text { Wspieranie bariery śródbłonkowej } \\
\text { Migracja i działanie komórek układu nerwowego } \\
\text { Działanie oligodendrocytów }\end{array}$ \\
\hline S1PR2 & $\begin{array}{l}\text { Komórki śródbłonka } \\
\text { Komórki mięśni gładkich }\end{array}$ & $\begin{array}{l}\text { Wspieranie bariery śródbłonkowej } \\
\text { Regulacja napięcia naczyń krwionośnych }\end{array}$ \\
\hline S1PR3 & $\begin{array}{l}\text { Komórki układu nerwowego } \\
\text { Komórki śródbłonka } \\
\text { Komórki mięśni gładkich }\end{array}$ & $\begin{array}{l}\text { Migracja i działanie komórek układu nerwowego } \\
\text { Wspieranie bariery śródbłonkowej } \\
\text { Regulacja napięcia naczyń krwionośnych } \\
\text { Kontrola rytmu serca }\end{array}$ \\
\hline S1PR4 & Limfocyty & $\begin{array}{l}\text { Modulacja działania limfocytów Th17 i komórek dendrytycznych } \\
\text { Skurcz naczyń krwionośnych }\end{array}$ \\
\hline S1PR5 & $\begin{array}{l}\text { Komórki nerwowe centralnego } \\
\text { układu nerwowego } \\
\text { Oligodendrocyty } \\
\text { Komórki NK }\end{array}$ & $\begin{array}{l}\text { Działanie oligodendrocytów } \\
\text { Migracja komórek NK }\end{array}$ \\
\hline
\end{tabular}




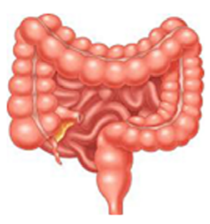

Niskie stężenie tkankowego S1P Niska ekspresja SphK1, SphK2 Wysoka ekspresja SPL

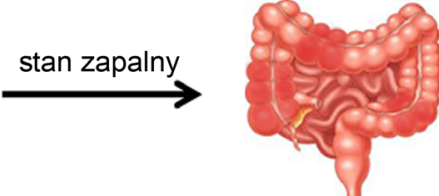

Akumulacja tkankowego S1P Wzrost ekspresji SphK1 i SphK2 Obniżenie ekspresji SPL
Rycina 3. Zmiany w metabolizmie S1P zachodzące w przebiegu NChZJ. S1P sfingozyno-1-fosforan, SphK1 - kinaza sfingozyny typu 1, SphK2 - kinaza sfingozyny typu 2, SPL - liaza sfingozyno-1-fosforanu.

[8]. Pod wpływem stanu zapalnego ekspresja kinaz S1P znacząco wzrasta, co w konsekwencji napędza produkcje S1P oraz prowadzi do jego akumulacji w tkance [9-12]. W mysim modelu zapalenia jelita wywołanego przez siarczan dekstranu sodu (DSS, ang. dextran sulfate sodium) wykazano, że u myszy z delecją genu dla SphK1 przebieg choroby jest zdecydowanie cięższy niż $\mathrm{w}$ grupie kontrolnej ze stanem zapalnym. U tych myszy wykazano odwrotną korelację pomiędzy nasileniem stanu zapalnego a poziomem S1P w jelitach [10]. W badaniu klinicznym na małej grupie pacjentów (6 pacjentów z NChZJ vs $3 \mathrm{w}$ grupie placebo) wykazano, że $\mathrm{w}$ bioptatach $\mathrm{z}$ jelita grubego pacjentów chorych ekspresja SphK1 na poziomie białkowym była wyższa niż u zdrowych uczestników badania. Co szczególnie interesujące, ekspresja SphK1 korelowała ze stopniem nasilenia patologii ocenionym podczas badania histopatologicznego [13]. W badaniu autorstwa Suh i wsp. [14] oceniono ekspresję genów dla SphK1, SphK2, SPL oraz receptorów S1PR w bioptatach jelita grubego $\mathrm{w}$ grupie młodych $(<18$. roku życia) pacjentów z NChZJ. Stwierdzono, że ekspresja tych genów (SphK1, SphK2, SPL, S1PR1, S1PR2 oraz S1PR4) była zwiększona u pacjentów ze średnim/wysokim stopniem nasilenia choroby $\mathrm{w}$ porównaniu do pacjentów pozostających $\mathrm{w}$ remisji lub zdrowej grupy kontrolnej. $\mathrm{W}$ analizie bazy danych GEO (GSE10616) [15], która zawiera informacje o genomie pacjentów z NChZJ, przeprowadzonej przez Suh i wsp. [14], wykazano, że ekspresja genów dla SphK1 i S1PR1 jest zwiększona w jelicie grubym pacjentów z NChZJ w porównaniu do kontroli, podczas gdy ekspresja dla SphK2 i S1PR2 były obniżone w stosunku do zdrowych pacjentów.
W warunkach homeostazy ekspresja i aktywność SPL w enterocytach jest wysoka. W mysim modelu raka jelita grubego rozwijającego się na podłożu przewlekłego stanu zapalnego w jelitach wykazano, że delecja genu dla SPL skutkuje nasileniem choroby oraz wywołuje znaczący wzrost poziomu cytokin prozapalnych $\mathrm{w}$ porównaniu do grupy kontrolnej. U myszy z delecją genu kodującego SPL w przebiegu zapalenia jelit dochodzi także do nagromadzenia S1P w jelitach oraz aktywacji ścieżki STAT3 [16]. Wykazano także, że w jelicie grubym pacjentów z NChZJ, stężenie we krwi fosforanu pirydoksalu (witaminy B6), będącego kofaktorem dla SPL, jest obniżone [17]. Ponadto, zaobserwowano odwrotną korelację między poziomem fosforanu pirydoksalu a S1P w jelitach $w$ mysim modelu zapalenia jelita grubego u myszy z delecją genu dla interleukiny 10 [18]. Rycina 3 podsumowuje zmiany zachodzące $w$ przebiegu zapalenia jelit związane z S1P oraz jego metabolizmem.

Do grupy modulatorów S1PR, mających potencjalne zastosowanie terapeutyczne w NChZJ należą związki, które farmakologicznie są agonistami S1PR. Związki te jednak, po wstępnej aktywacji receptora, prowadzą następnie do jego internalizacji i w efekcie zmniejszenia ekspresji na powierzchni komórki [19]. Leki tej grupy ze względu na swoje działanie przeciwzapalne i neuroprotekcyjne są z powodzeniem stosowane $\mathrm{w}$ terapii stwardnienia rozsianego (fingolimod od 2010 roku, siponimod od 2019 roku) [20]. Wpływają korzystnie na przebieg choroby: przyczyniają się do złagodzenia objawów oraz wprowadzają pacjenta w stan remisji. Szczegółowy mechanizm działania modulatorów receptora dla S1P został opisany poniżej na przykładzie fingolimodu, pierwszego poznanego związku należącego do tej grupy (Ryc. 4) [19].

\section{MODULATORY RECEPTORA DLA S1P A NChZJ}

\section{FINGOLIMOD}

Fingolimod jest pierwszym znanym i tym samym najlepiej przebadanym modulatorem receptora dla S1P. Fingolimod działa jak funkcjonalny antagonista receptora: po wstępnej aktywacji wywołuje internalizację i ubikwitynację receptora, w konsekwencji uniemożliwia jego dalsze pobudzanie oraz prowadzi do zmniejszenia ekspresji

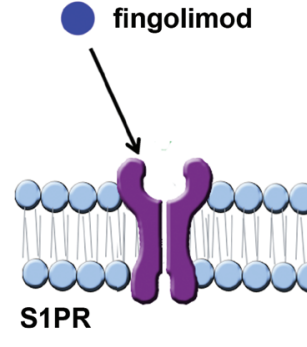

Aktywacja receptora

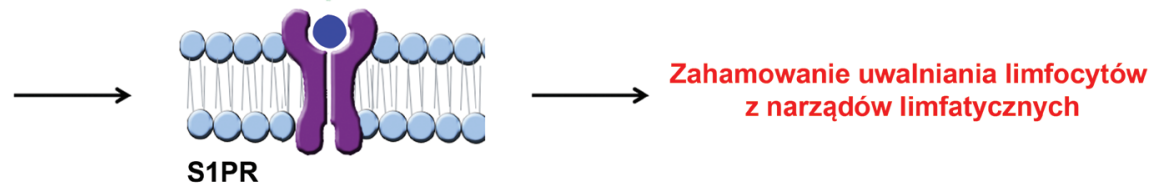

Internalizacja receptora S1PR1

na powierzchni limfocytów

Ubikwitynacja receptora S1PR1

Obniżenie ekspresji mRNA dla S1PR1

Rycina 4. Mechanizm działania modulatorów receptora dla S1P na przykładzie fingolimodu. S1PR - receptor sfingozyno-1-fosforanu. 
receptora na powierzchni komórek. Skutkiem działania fingolimodu jest spadek liczby krążących w krwioobiegu limfocytów: T, Th oraz B (ze względu na zablokowanie ich uwalniania $\mathrm{z}$ narządów limfatycznych) [21,22]. Ponadto wykazano, że te limfocyty B, które obecne są we krwi podczas leczenia fingolimodem charakteryzują się upośledzoną zdolnością do uwalniania cytokin oraz zmniejszoną żywotnością, w porównaniu do tych samych komórek u pacjentów, którzy nie byli leczeni tym lekiem [23]. Wpływ fingolimodu na komórki układu odpornościowego widoczny jest już po kilku godzinach od jego podania [24,25]. Długofalowe skutki stosowania fingolimodu obejmują nasilenie działania przeciwzapalnego komórek prezentujących antygen [26] oraz przesunięcie równowagi pomiędzy pro- i przeciwzapalnymi komórkami i cytokinami w stronę fenotypu o mniejszym nasileniu stanu zapalnego [27].

Wyniki badań in vivo zgodnie wskazują na korzystny wpływ fingolimodu na przebieg NChZJ w modelach zwierzęcych. Wykazano, że przeciwzapalne działanie fingolimodu wynika z: zahamowania infiltracji błony śluzowej $\mathrm{w}$ jelicie grubym przez komórki T CD4+ [28], zahamowania różnicowania komórek Th17 [29] (bardzo istotnych w patogenezie NChZJ), oraz Th1 [30], pobudzania różnicowania komórek Treg [30,31], obniżenia syntezy prozapalnych cytokin [32].

Wieloletnie stosowanie fingolimodu w terapii stwardnienia rozsianego pozwoliło na scharakteryzowanie profilu bezpieczeństwa tego leku. Ze względu na jego działania uboczne (szczególnie te związane z wpływem leku na układ krążenia) potencjalne zastosowanie tego leku w terapii NChZJ jest ograniczone [33]. W jego miejsce proponowane są modulatory receptora S1P nowszej generacji, charakteryzujące się bardziej selektywnym działaniem, porównywalną skutecznością oraz niższym ryzykiem wystąpienia działań ubocznych. Do tej grupy zaliczane są: ozanimod, etrasimod, czy amiselimod (Ryc. 5).

\section{OZANIMOD}

Ozanimod (RPC1063) jest pierwszym spośród modulatorów receptora dla S1P, który został włączony do badań klinicznych u pacjentów z NChZJ. W porównaniu do fingolimodu, ozanimod charakteryzuje się większą selektywnością (S1PR1 oraz S1P5). Dzięki temu związek ten cechuje niższy potencjał do wywoływania działań ubocznych (w szczególności tych związanych z układem krążenia) [34]. Działanie przeciwzapalne ozanimodu (w dawce 1,2 mg/ $\mathrm{kg}$, podawanego per os) zostało wykazane w dwóch modelach zapalenia jelit u szczurów: w modelu wywołanym podaniem kwasu 2,4,6-trinitrobenzenosulfonowego (TNBS) oraz wywołanym transferem limfocytów $\mathrm{CD} 4{ }^{+} \mathrm{CD} 45 \mathrm{Rb} \mathrm{b}^{\text {high }} \mathrm{T}$ u myszy z wyciszonym układem odpornościowym [35]. U badanych zwierząt odnotowano poprawę w zakresie parametrów klinicznych, laboratoryjnych wskaźników stanu zapalnego oraz w obrazie histopatologicznym.

Sandborn i wsp. [36] przeprowadzili randomizowane badanie kliniczne z podwójnie ślepą próbą, w którym ocenili skuteczność ozanimodu u dorosłych pacjentów z WZJG. Pacjenci otrzymywali lek w dawce $1 \mathrm{mg}$ lub 0,5 mg, lub placebo przez 32 tygodnie. Pierwszorzędowym punktem koncowym badania było wywołanie remisji choroby (wynik w skali Mayo Clinic wynosił $\leq 2$ w 8. tygodniu leczenia). Cel ten został osiągnięty przez $16 \%$ pacjentów otrzymujących lek $\mathrm{w}$ dawce $1 \mathrm{mg}, 14 \%$ pacjentów leczonym ozanimodem $\mathrm{w}$ dawce $0,5 \mathrm{mg} \mathrm{w}$ porównaniu do zaledwie $6 \%$ pacjentów z grupy placebo. Warto zaznaczyć, że wynik leczenia ozanimodem w niższej dawce nie był istotny statystycznie. Drugorzędowy punkt końcowy badania obejmował poprawę parametrów klinicznych po 8 tygodniach leczenia, określoną jako zmniejszenie wyniku w skali Mayo Clinic o $\geq 3$ punkty i o $\geq 30 \% \mathrm{w}$ stosunku do wartości wyjściowej z towarzyszącą poprawą zakresie krwawienia z dystalnej części jelita grubego. Poprawę parametrów klinicznych zaobserwowano u 57 i 54\% (odpowiednio ozanimod 1 i 0,5 mg) vs. $37 \%$ pacjentów w grupie placebo. Korzystny wpływ ozanimodu został potwierdzony podczas oceny parametrów

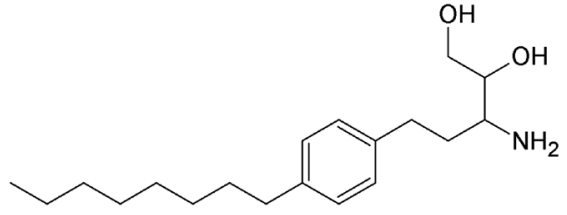

fingolimod

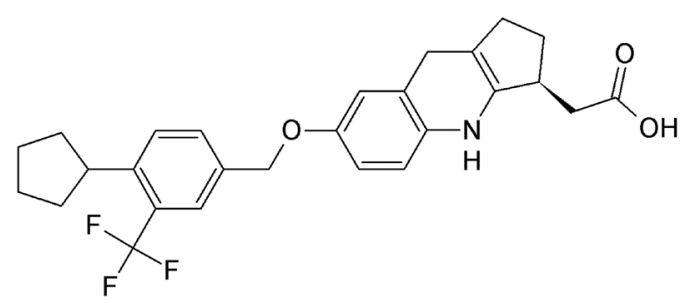<smiles>CC(C)Oc1ccc(-c2nc(-c3cccc4c3CC[C@H]4NCCO)no2)cc1C#N</smiles>

ozanimod

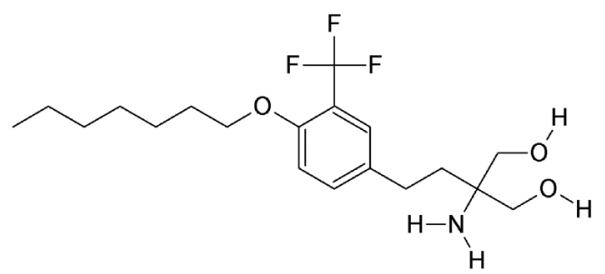

etrasimod

amiselimod

Rycina 5. Struktury modulatorów S1PR: fingolimodu, ozanimodu, etrasimodu oraz amiselimodu. 
klinicznych w 32. tygodniu leczenia: 21 i 26\% (ozanimod 1 i $0,5 \mathrm{mg}$ ) vs. $6 \%$ pacjentów w grupie placebo osiągnęło drugorzędowy punkt końcowy. Nie odnotowano poważnych skutków ubocznych podczas leczenia ozanimodem [36].

W styczniu 2019 roku zaprezentowano wstępne wyniki badania klinicznego drugiej fazy nad działaniem ozanimodu u pacjentów z aktywną postacią ChLC [37]. W 12. tygodniu badania klinicznego ocenie histopatologicznej poddane zostały fragmenty dystalnej części jelita cienkiego, poszczególnych części okrężnicy i odbytnicy pobrane od pacjentów przyjmujących lek w dawce $1 \mathrm{mg}$ dziennie podczas badania endoskopowego. U pacjentów leczonych ozanimodem zaobserwowano poprawę w zakresie histopatologicznych wskaźników stanu zapalnego we wszystkich przebadanych fragmentach przewodu pokarmowego [37].

\section{ETRASIMOD}

Etrasimod (APD334) jest kolejnym spośród modulatorów S1PR nowej generacji, będącym agonistą S1PR1, S1PR4 i S1PR5. Etrasimod (w dawce $3 \mathrm{mg} / \mathrm{kg}$, per os) skutecznie złagodził stan zapalny $\mathrm{w}$ zwierzęcym modelu zapalenia jelita grubego wywołanym transferem limfocytów $\mathrm{CD} 4{ }^{+} \mathrm{CD} 45 \mathrm{R}-$ $\mathrm{b}^{\text {high }} \mathrm{T} \mathrm{u}$ myszy $\mathrm{z}$ wyciszonym układem odpornościowym. Wykazano, że u myszy leczonych etrasimodem doszło do obniżenia liczby krążących w krwioobiegu limfocytów [38].

Obecnie prowadzone są badania kliniczne nad działaniem etrasimodu u pacjentów z NChZJ. W 2018 roku zakończyły się dwa badania kliniczne drugiej fazy u pacjentów z WZJG [39,40]. W roku 2019 rozpoczęto badania trzeciej fazy $[41,42]$.

\section{AMISELIMOD}

Do grupy modulatorów S1PR nowej generacji należy także selektywny agonista S1PR1 jakim jest amiselimod (MT1303). Amiselimod cechuje wysoka aktywność (jego wartość EC50 jest niższa niż dla pozostałych poznanych do tej pory agonistów S1PR1) oraz, ze względu na swoją selektywność względem jednego z typów receptorów dla S1P, korzystny profil bezpieczeństwa. W badaniach przedklinicznych opublikowanych w grudniu 2019 roku wykazano, że związek ten $\mathrm{w}$ dawce 0,1 oraz $0,3 \mathrm{mg} / \mathrm{kg}$ (podawany raz dziennie przez tydzień) wykazuje silne działanie przeciwzapalne w mysim modelu NChZJ wywołanym transferem limfocytów $\mathrm{CD} 4^{+} \mathrm{CD} 45 \mathrm{Rb}^{\text {high }} \mathrm{T}$. Potencjał przeciwzapalny amiselimodu był porównywalny do terapii biologicznej skierowanej przeciwko TNFa [43].

Działanie przeciwzapalne amiselimodu zostało ocenione w badaniu klinicznym drugiej fazy u pacjentów z aktywną postacią ChLC $[44,45]$. Pacjenci przyjmowali amiselimod $\mathrm{w}$ dawce 0,4 mg codziennie przez 14 tygodni. Pierwszorzędowym punktem końcowym badania była poprawa w zakresie aktywności choroby, oceniona z wykorzystaniem skali Crohn's disease activity index (CDAI) (spadek w skali o 100 punktów w 12. tygodniu badania). Zaobserwowano, że pierwszorzędowy punkt końcowy został osiągnięty przez 48,7\% pacjentów (vs 54,1\% w grupie placebo). Nie zaobserwowano różnic pomiędzy grupą przyjmującą lek a grupą placebo w zakresie parametrów stanu zapalnego (białko C-reaktywne, kalprotektyna w kale). W 4. tygodniu badania odnotowano obniżenie liczby krążących we krwi limfocytów (obniżenie o 47,7\% w stosunku do wartości wyjściowej). Autorzy ocenili, że obserwowany spadek liczby limfocytów był mniejszy niż spodziewany. Sugerują także, że może to przekładać się na brak skuteczności badanego leku w porównaniu do wysokiej odpowiedzi klinicznej w grupie kontrolnej.

\section{PERSPEKTYWY}

Sfingozyno-1-fosforan ze względu na swoją istotną rolę w funkcjonowaniu układu odpornościowego stanowi ciekawy cel terapeutyczny w chorobach wywołanych nadmiernym stanem zapalanym. W związku z tym, że w przebiegu NChZJ obserwuje się nagromadzenie S1P w jelitach celem terapii może być dążenie do obniżenia jego poziomu. Dlatego też opracowano przeciwciało monoklonalne skierowane przeciwko S1P (sphingomab) [46]. Do tej pory skuteczność sphingomabu nie została oceniona w modelach naśladujących przebieg NChZJ, jednak istnieje prawdopodobieństwo, że wyciszenie działania S1P mogłoby przyczynić się do złagodzenia stanu zapalnego w jelitach. Do tej pory wykazano, że sphingomab w badaniach na komórkach ludzkich wykazano hamujący wpływ na wzrost guza [47].

Oprócz przeciwciał monoklonalnych skierowanych przeciwko S1P do zmniejszenia jego stężenia przyczynić się może także zahamowanie aktywności kinaz sfingozynowych. W badaniach na modelach zwierzęcych NChZJ wykazano, że u myszy pozbawionych genu kodującego SphK1, stan zapalny jelita grubego wywołany DSS był zdecydowanie mniej nasilony niż u myszy typu dzikiego [10]. Przebadano działanie przeciwzapalne jednego z inhibitorów SphK1, ABC294640 (50 mg/kg, per os) w mysim modelu zapalenia jelit wywołanego TNBS. Zaobserwowano, że związek ten zahamował progresję choroby, co było widoczne zarówno podczas oceny stanu klinicznego zwierząt, oceny makroskopowej i mikroskopowej jelita oraz podczas monitorowania poziomu cytokin prozapalnych [13].

Zahamowanie SPL także może stanowić ciekawą opcję terapeutyczną ze względu na wpływ na zmniejszenie gradientu stężeń S1P między krwią/limfą a narządami limfatycznymi. Zmniejszenie gradientu może przyczynić się do złagodzenia stanu zapalnego przez ograniczenie uwalniania limfocytów z węzłów chłonnych. Zaobserwowano, że w komórkach raka jelita grubego ekspresja SPL była obniżona, co doprowadziło do nagromadzenia zewnątrzkomórkowego S1P $[48,49]$. W jednym z badań wykazano, że delecja genu dla SPL w komórkach nabłonka jelitowego przyczyniła się do procesu transformacji guza poprzez aktywacje ścieżki STAT3 [50,51], której nadmierną aktywację opisuje się w komórkach nabłonkowych jelita u pacjentów z ChLC [52]. Tym samym aktywacja ścieżki STAT3 może wywierać niekorzystne działanie u pacjentów z NChZJ, np. przez szkodliwy wpływ na integralność błony śluzowej jelita [53].

Istotną rolę w przebiegu NChZJ mogą mieć także sfingolipidy spożywane $\mathrm{w}$ diecie. $\mathrm{W}$ jednym $\mathrm{z}$ badań na zwierzętach wykazano, że pod wpływem suplementacji sfingolipi- 
dami pochodzenia roślinnego powstawanie guzów w jelicie grubym było zredukowane. Ponadto, doustna podaż tych związków spowodowała wzrost poziomu SPL w jelitach, obniżyła poziom nagromadzonego S1P oraz cytokin prozapalnych, a także zahamowała aktywność ścieżki STAT3. Autorzy badania wskazują na istotną rolę sfingolipidów w diecie w prewencji i w przebiegu raka jelita grubego [16].

\section{PODSUMOWANIE}

Sfingozyno-1-fosforan jest niezwykle ważnym mediatorem, który uczestniczy w wielu procesach biologicznych, $\mathrm{w}$ tym m.in. w zapewnianiu integralności warstwy nabłonkowej, czy w reakcji zapalnej. W badaniach $\mathrm{z}$ ostatnich lat zwrócono uwage na istotny wpływ S1P i jego metabolizmu na przebieg zapalenia w obrębie jelit i wskazano tę cząsteczkę jako potencjalny cel w terapii NChZJ. Modulatory receptora dla S1P, dostępne w formie doustnej, mogą okazać się interesującą alternatywą dla obecnie stosowanych terapii ze względu na swoją wysoką skuteczność, korzystny profil farmakologiczny (m.in. wysoką biodostępność) oraz bezpieczeństwo stosowania.

\section{PIŚMIENNICTWO:}

1. Liu H, Sugiura M, Nava VE, Edsall LC, Kono K, Poulton S, et al. (2000) Molecular cloning and functional characterization of a novel mammalian sphingosine kinase type 2 isoform. J Biol Chem 275: 19513-19520

2. Igarashi N, Okada T, Hayashi S, Fujita T, Jahangeer S, Nakamura SI (2003) Sphingosine kinase 2 is a nuclear protein and inhibits DNA synthesis. J Biol Chem 278: 46832-46839

3. Hänel P, Andréani P, Gräler MH (2000) Erythrocytes store and release sphingosine 1-phosphate in blood. FASEB J 21: 1202-1209

4. Rosen H, Gonzalez-Cabrera PJ, Sanna MG, Brown S (2009) Sphingosine 1-Phosphate receptor signaling. Annu Rev Biochem 78: 743-768

5. Schwab SR, Cyster JG (2007) Finding a way out: lymphocyte egress from lymphoid organs. Nat Immunol 8: 1295-1301

6. Alvarez SE, Harikumar KB, Hait NC, Allegood J, Strub GM, Kim EY, et al. (2010) Sphingosine-1-phosphate is a missing cofactor for the E3 ubiquitin ligase TRAF2. Nature 465: 1084-1088

7. Lee H, Deng J, Kujawski M, Yang C, Liu Y, Herrmann A, et al. (2010) STAT3-induced S1PR1 expression is crucial for persistent STAT3 activation in tumors. Nat Med 16: 1421-1428

8. Borowsky AD, Bandhuvula P, Kumar A, Yoshinaga Y, Nefedov M, Fong LG, et al. (2012) Sphingosine-1-phosphate lyase expression in embryonic and adult murine tissues. J Lipid Res 53: 1920-1931

9. Maines LW, Fitzpatrick LR, French KJ, Zhuang Y, Xia Z, Keller SN, et al. (2008) Suppression of ulcerative colitis in mice by orally available inhibitors of sphingosine kinase. Dig Dis Sci 53: 997-1012

10. Snider AJ, Kawamori T, Bradshaw SG, Orr KA, Gilkeson GS, Hannun YA, et al. (2009) A role for sphingosine kinase 1 in dextran sulfate sodium-induced colitis. FASEB J 23: 143-152

11. Chumanevich AA, Poudyal D, Cui X, Davis T, Wood PA, Smith CD, et al. (2010) Suppression of colitis-driven colon cancer in mice by a novel small molecule inhibitor of sphingosine kinase. Carcinogenesis 31: 1787-1793

12. Abdin AA (2013) Targeting sphingosine kinase 1 (SphK1) and apoptosis by colon-specific delivery formula of resveratrol in treatment of experimental ulcerative colitis in rats. Eur J Pharmacol 718: 145153

13. Maines LW, Fitzpatrick LR, Green CL, Zhuang Y, Smith CD (2010) Efficacy of a novel sphingosine kinase inhibitor in experimental Crohn's disease. Inflammopharmacology 18: 73-85

14.Suh JH, Degagné É, Gleghorn EE, Setty M, Rodriguez A, Park KT, et al. (2018) Sphingosine-1-Phosphate Signaling and Metabolism Gene
Signature in Pediatric Inflammatory Bowel Disease: A Matched-case Control Pilot Study. Inflamm Bowel Dis 24

15. Human colon expression in healthy controls, colon-only $\mathrm{CD}$, ileo-colonic CD, and UC. GEO Accession viewer. https://www.ncbi. nlm.nih.gov/geo/query / acc.cgi?acc=GSE10616

16. Degagné E, Pandurangan A, Bandhuvula P, Kumar A, Eltanawy A, Zhang M, et al. (2014) Sphingosine-1-phosphate lyase downregulation promotes colon carcinogenesis through STAT3-activated microRNAs. J Clin Invest 124: 5368-5384

17.Saibeni S, Cattaneo M, Vecchi M, Zighetti ML, Lecchi A, Lombardi $\mathrm{R}$, et al. (2003) Low vitamin B6 plasma levels, a risk factor for thrombosis, in inflammatory bowel disease: Role of inflammation and correlation with acute phase reactants. Am J Gastroenterol 98: 112-117

18. Selhub J, Byun A, Liu Z, Mason JB, Bronson RT, Crott JW (2013) Dietary vitamin B6 intake modulates colonic inflammation in the IL10-/- model of inflammatory bowel disease. J Nutr Biochem 24: 2138-2143

19.Subei AM, Cohen JA (2015) Sphingosine 1-phosphate receptor modulators in multiple sclerosis. CNS Drugs 29: 565-575

20.Goodman AD, Anadani N, Gerwitz L (2019) Siponimod in the treatment of multiple sclerosis. Expert Opin Investig Drugs 28: 10511057

21. Matloubian M, Lo CG, Cinamon G, Lesneski MJ, Xu Y, Brinkmann $V$, et al. (2004) Lymphocyte egress from thymus and peripheral lymphoid organs is dependent on S1P receptor 1. Nature 427: 355-360

22. Brinkmann V, Davis MD, Heise CE, Albert R, Cottens S, Hof R, et al. (2002) The immune modulator FTY720 targets sphingosine 1-phosphate receptors. J Biol Chem 277: 21453-21457

23. Blumenfeld S, Staun-Ram E, Miller A (2016) Fingolimod therapy modulates circulating B cell composition, increases B regulatory subsets and production of IL-10 and TGF $\beta$ in patients with Multiple Sclerosis. J Autoimmun 70: 40-51

24. Yopp AC, Ochando JC, Mao M, Ledgerwood L, Ding Y, Bromberg JS (2005) Sphingosine 1-phosphate receptors regulate chemokine-driven transendothelial migration of lymph node but not splenic $\mathrm{T}$ cells. J Immunol 175: 2913-2924

25. Baumruker T, Billich A, Brinkmann V (2007) FTY720, an immunomodulatory sphingolipid mimetic: Translation of a novel mechanism into clinical benefit in multiple sclerosis. Expert Opinion on Investigational Drugs 16: 283-289

26. Luessi F, Kraus S, Trinschek B, Lerch S, Ploen R, Paterka M, et al. (2015) FTY720 (fingolimod) treatment tips the balance towards less immunogenic antigen-presenting cells in patients with multiple sclerosis. Mult Scler 21: 1811-1822

27. Mullershausen F, Zecri F, Cetin C, Billich A, Guerini D, Seuwen K. (2009) Persistent signaling induced by FTY720-phosphate is mediated by internalized S1P1 receptors. Nat Chem Biol 5: 428-434

28. Deguchi Y, Andoh A, Yagi Y, Bamba S, Inatomi O, Tsujikawa T, et al. (2006) The S1P receptor modulator FTY720 prevents the development of experimental colitis in mice. Oncol Rep 16: 699-703

29. Mehling M, Lindberg R, Raulf F, Kuhle J, Hess C, Kappos L, et al. (2010) Th17 central memory T cells are reduced by FTY720 in patients with multiple sclerosis. Neurology 75(5):403-10

30. Daniel C, Sartory NA, Zahn N, Schmidt R, Geisslinger G, Radeke $\mathrm{HH}$, et al. (2007) FTY720 ameliorates oxazolone colitis in mice by directly affecting $\mathrm{T}$ helper type 2 functions. Mol Immunol 44: 33053316

31. Liu G, Yang K, Burns S, Shrestha S, Chi H (2010) The S1P1-mTOR axis directs the reciprocal differentiation of TH1 and Treg cells. Nat Immunol 11: 1047-1056

32. Liang J, Nagahashi M, Kim EY, Harikumar KB, Yamada A, Huang W-C, et al. (2013) Sphingosine-1-phosphate links persistent STAT3 activation, chronic intestinal inflammation, and development of colitis-Aassociated cancer. Cancer Cell 23: 107-120

33. Kappos L, O'Connor P, Radue EW, Polman C, Hohlfeld R, Selmaj $\mathrm{K}$, et al. (2015) Long-term effects of fingolimod in multiple sclerosis. Neurology 84: 1582-1591 
34. Cohen JA, Arnold DL, Comi G, Bar-Or A, Gujrathi S, Hartung JP, et al. (2016) Safety and efficacy of the selective sphingosine 1-phosphate receptor modulator ozanimod in relapsing multiple sclerosis (RADIANCE): a randomised, placebo-controlled, phase 2 trial. Lancet Neurol 15: 373-381

35. Scott FL, Clemons B, Brooks J, Brahmachary E, Powell R, Dedman $\mathrm{H}$, et al. (2016) Ozanimod (RPC1063) is a potent sphingosine-1-phosphate receptor-1 $\left(\mathrm{S}_{1} \mathrm{P}_{1}\right)$ and receptor-5 $\left(\mathrm{S}_{\mathrm{P}}\right)$ agonist with autoimmune disease-modifying activity. Br J Pharmacol 173: 1778-1792

36. Sandborn WJ, Feagan BG, Wolf DC, D'Haens G, Vermeire S, Hanauer SB, et al. (2016) Ozanimod induction and maintenance treatment for ulcerative colitis. N Engl J Med 374: 1754-1762

37. Feagan BG, D’Haens G, Usiskin K, Liu J, Paul D, Pai RK (2019) P661 Early histological improvement demonstrated with oral ozanimod in patients with moderately to severely active Crohn's disease in the STEPSTONE trial. J Crohn's Colitis 13 (Supplement_1): S450-S450

38. Adams JW, Solomon M, Lehmann-Bruinsma K, Carroll C, He H, Behan D, Al-Shamma H (2017) Etrasimod (APD334), an oral, next-generation sphingosine-1-phosphate receptor modulator inhibits the development of colitis in lymphoid-null mice injected with colitogenic CD4+ T cells. FASEB J 31 (Supplement_1)

39. Safety and Efficacy of Etrasimod (APD334) in Patients With Ulcerative Colitis. https:/ / clinicaltrials.gov/ct2/show/NCT02447302?ter$\mathrm{m}=\mathrm{APD} 334 \&$ draw $=2 \& \mathrm{rank}=5$

40. Extension Study of APD334-003 in Patients With Moderately to Severely Active Ulcerative Colitis. https://clinicaltrials.gov/ct2/ show $/$ NCT02536404? term =APD334\&draw $=2 \&$ rank $=4$

41. An Extension Study for Treatment of Moderately to Severely Active Ulcerative Colitis. https://clinicaltrials.gov/ct2/show/ NCT03950232?term $=$ APD334\&draw $=2 \&$ rank $=6$

42. Etrasimod Versus Placebo as Induction Therapy in Moderately to Severely Active Ulcerative Colitis. https://clinicaltrials.gov/ct2/ show $/$ NCT03996369?term=APD334\&draw=2\&rank=7

43. Shimano K, Maeda Y, Kataoka H, Murase M, Mochizuki S, Utsumi $\mathrm{H}$, et al. (2019) Amiselimod (MT-1303), a novel sphingosine 1-phosphate receptor-1 functional antagonist, inhibits progress of chronic colitis induced by transfer of CD4+CD45RBhigh T cells. PLoS One 14: $\mathrm{e} 0226154$

44. D'Haens G, Danese S, Davies M, Watanabe M, Hibi T (2019) DOP48 Amiselimod, a selective S1P receptor modulator in Crohn's disease patients: a proof-of-concept study. J Crohn's Colitis 13 (Supplement_1): S055-S056

45. D’Haens GR, Danese S, Hibi T, Watanabe M, Davies M (2019) 1005 A controlled trial of amiselimod, a selective S1P receptor modulator in Crohn's isease. Gastroenterology 156: S-217.

46.Sugahara K, Maeda Y, Shimano K, Mogami A, Kataoka H, Ogawa $\mathrm{K}$, et al. (2017) Amiselimod, a novel sphingosine 1-phosphate receptor-1 modulator, has potent therapeutic efficacy for autoimmune diseases, with low bradycardia risk. Br J Pharmacol 174: 15-27

47. Visentin B, Vekich JA, Sibbald BJ, Cavalli AL, Moreno KM, Matteo RG, et al. (2006) Validation of an anti-sphingosine-1-phosphate antibody as a potential therapeutic in reducing growth, invasion, and angiogenesis in multiple tumor lineages. Cancer Cell 9: 225-238

48. Fyrst H, Saba JD (2010) An update on sphingosine-1-phosphate and other sphingolipid mediators. Nat Chem Biol 6: 489-497

49. Schwab SR, Pereira JP, Matloubian M, Xu Y, Huang Y, Cyster JG (2005) Immunology: Lymphocyte sequestration through S1P lyase inhibition and disruption of S1P gradients. Science 309: 1735-1739

50. Chapman RS, Lourenco P, Tonner E, Flint D, Selbert S, Takeda K, et al. (2000) The role of Stat3 in apoptosis and mammary gland involution. Adv Exp Med Biol 480: 129-138

51. Levy DE, Darnell JE (2002) STATs: Transcriptional control and biological impact. Nat Rev Mol Cell Biol 3: 651-662

52. Neufert C, Pickert G, Zheng Y, Wittkopf N, Warntjen M, Nikolaev A, et al. (2010) Activation of epithelial STAT3 regulates intestinal homeostasis. Cell Cycle 9: 652-655

53. Prager M, Büttner J, Haas V, Baumgart DC, Sturm A, Zeitz M, et al. (2012) The JAK2 variant rs10758669 in Crohn's disease: Altering the intestinal barrier as one mechanism of action. Int J Colorectal Dis 27: $565-573$

\title{
The place of sphingosine-1-phosphate modulators in the therapy of inflammatory bowel diseases
}

\author{
Kamil Szymaszkiewicz ${ }^{1}$, Agata Szymaszkiewicz² ${ }^{2}$ Jakub Fichna ${ }^{2 \varpi}$
}

${ }^{1}$ Department of Pharmacology and Toxicology, Faculty of Medicine, Medical University of Lodz, Lodz, Poland

${ }^{2}$ Department of Biochemistry, Faculty of Medicine, Medical University of Lodz, Lodz, Poland

${ }^{\square}$ Corresponding author: jakub.fichna@umed.lodz.pl

Key words: Crohn's disease, fingolimod, inflammatory bowel disease, sphingosine-1-phosphate, ulcerative colitis

\section{SUMMARY}

Sphingosine-1-phosphate (S1P) belongs to the group of biologically active sphingolipids. Because of its ability to regulate the migration of lymphocytes, S1P constitutes an important element of pathophysiology of several diseases, such as: lupus erythematosus, multiple sclerosis or inflammatory bowel diseases. Inflammatory bowel diseases (IBD) are the group of chronic and recurrent diseases of the gastrointestinal tract. The most common among IBD are: Crohn's disease and ulcerative colitis. Drugs that are currently used in the therapy of IBD alleviate symptoms, improve patients' quality of life and induce remission but their efficacy is not satisfactory. Modulators of S1P receptors constitute an emerging option in the therapy of IBD. In this review we will discuss the role of S1P, its receptor and enzymes that participate in the metabolism of S1P under physiological conditions and in the course of IBD. Moreover, we will sum up the results of preclinical and clinical studies on S1P receptors modulators in IBD. 